\title{
Back from the brink: Labor's re-election at the 2017 Queensland state election
}

\author{
Paul D. Williams \\ paul.williams@griffith.edu.au
}

\begin{abstract}
History will record the 2017 Queensland state election not only for its series of firsts - Annastacia Palaszczuk is the first woman state premier to win two successive elections - but also because it defied expectations. Despite its own lack-lustre campaign, an inauspicious economic climate and the revival of Pauline Hanson's One Nation (PHON), Palaszczuk's Labor Government enjoyed a small after-preference swing to it (despite a small primary swing against it) to win four additional seats and, with it, its first majority in the Legislative Assembly. Conversely, the Liberal-National Party (LNP) lost three seats in a significant primary swing against it, while $\mathrm{PHON}$, after a chaotic campaign, won a just single seat in a statewide primary vote that fell well below expectations. This article argues that these unexpected results can be attributed to a number of factors, ranging from Palaszczuk's relative popularity to voters' desire for stable government to their disdain for an opposition (and opposition leader) many conflated with both PHON and former LNP Premier Campbell Newman. The article also suggests the election of the first majority government since 2012 could mark the stabilising of a hitherto volatile Queensland electorate as Palaszczuk appears to extend Labor's second electoral hegemony.
\end{abstract}

\section{Introduction}

The 2017 Queensland election is notable for its series of firsts. To date, Annastacia Palaszczuk remains the only woman state premier to have won office from opposition (2015) and the only woman premier to have won two successive elections. ${ }^{1}$ This election also saw the election of the first Greens MP (Michael Berkman, Maiwar), ${ }^{2}$ the first Torres Strait Islander MP (Cynthia Lui, Labor, Cook) and the first South Sea Islander MP (Stephen Andrew, Mirani), who is also the first Pauline Hanson's One Nation (PHON) MP elected since 2009. This election was also the first since 1989 to use compulsory preferential voting (CPV), the first under 'real-time' electoral donation declaration laws, the first since the repeal of voter identification legislation and the first occasion since $1907^{3}$ to see a minority government re-elected. 
The 2017 election is Queensland's third extraordinary poll in succession. Where the 2012 election saw the largest parliamentary majority in Australian history, ${ }^{4}$ the 2015 election saw an equally astonishing 14 per cent two party-preferred (2PP) return swing to Labor and the defeat of a first-term government. Similarly, this election saw Palaszczuk's Labor Party, despite its ostensibly confused campaign and precarious incumbency, endure only a small negative 2.04 per cent primary swing. Labor also managed to win four additional seats (and majority government) with a 0.1 per cent 2PP swing towards it, despite the challenge of a united Liberal-National Party (LNP), consistently high unemployment figures and a resurgent PHON. It is equally remarkable the LNP, despite its comparatively smooth campaign under experienced leader Tim Nicholls, should lose seats in a hefty primary swing that, at 7.63 per cent, approximated its 2015 collapse. ${ }^{5}$

The research questions driving this article are clear: How did Palaszczuk's government remain electorally competitive over the triennium? Why did Nicholls' leadership fail to gain traction, and why did the LNP's vote decline so sharply? Why did The Greens win the seat of Maiwar but not the seat of South Brisbane despite the party's high-profile campaign there? And why did PHON fail to win more seats?

In response, I posit eight arguments: first, that the electorate's desire for political stability and majority government was a primary motivation for voters despite a significant proportion believing the Palaszczuk government did not deserve re-election; second, that Palaszczuk, relative to Nicholls, remained popular among voters; third, that Labor's first term - in contrast to the Newman Government (2012-15) remained consultative and largely risk-averse in its 'de-Newmanisation' process; fourth, that Nicholls failed to adequately distance his legacy from his role as Treasurer in the Newman government; fifth, that Nicholls appeared disingenuous in his claims of not accepting PHON support for any minority government; sixth, that LNP preferencing of PHON above Labor in 49 seats damaged the LNP's credibility, especially in Brisbane; seventh, that PHON's gaffe-prone campaign including Senator Fraser Anning's resignation - and its rhetorical over-reach cost the party votes; and eighth, that the Adani coal mine (and attendant loan) was not the highly salient issue the news media suggested. In examining these theses, my method is to qualitatively compare and contrast the events of Queensland's fifty-fifth parliament and, more specifically, the four-week election campaign, and to measure those events against quantitative data around voters' issue salience and public opinion support for the parties and their leaders. A final analysis of results is then offered before conclusions are drawn about the significance of the 2017 election.

\section{The fifty-fifth parliament}

In contrast to Queensland's long history of large and long-enduring electoral hegemonies (Williams 2001, 2004, 2005, 2007, 2010), the state's fifty-fifth parliament produced Queensland's third minority government in two decades, and one arguably with more political colour than either the Borbidge Coalition (1996-98) or Beattie Labor (1998) minority administrations. The Palaszczuk Cabinet, for only the second time in Australian history, ${ }^{6}$ also boasted a woman Premier and Deputy Premier and, rarely for Queensland, saw Labor's Left faction comprise almost half 
the caucus and ministry. With Labor Unity (Old Guard) factional support, the Left effectively controlled the Palaszczuk Cabinet - initially of just fourteen ministers, and later seventeen - as it embarked upon a 'de-Newmanisation' process that repealed much of former Liberal-National (LNP) Premier Campbell Newman's reforms. Palaszczuk cancelled asset privatisation, repealed controversial anti-bikie 'VLAD' laws, pledged an earlier termination of sand mining on Stradbroke Island, reinstated the Premier's Literary Awards, returned the Labour Day holiday to May, scrapped the Brisbane Bus and Train Tunnel plan, repealed contentious voter identification laws, introduced 'real-time' declarations for political donations above $\$ 1,000$ and abandoned plans for electricity deregulation. As part of a strategy to distinguish itself from the allegedly non-consultative Newman government, Labor launched more than 200 public inquiries and policy reviews in areas ranging from child abuse to 'black lung' disease to alcohol management. This cautious approach attracted opprobrium, however, and Labor was described as an 'accidental' and 'do nothing' government that prioritised social policy — for example, expunging historic homosexual criminal convictions and removing seventeen-year-olds from adult prisons - at the expense of economic reform (Egan 2017). The Palaszczuk government - like the Newman and Bligh administrations before it - also suffered a perception among regional voters of governing primarily from, and for, South-East Queensland (McKenna 2016).

Palaszczuk's leadership was severely tested by members of her own government. Just weeks after the election, it was revealed that newly elected Cook MP Billy Gordon had a lengthy criminal record (Williams 2015). Palaszczuk expelled Gordon from the caucus in March 2015; after refusing to resign from parliament, he sat as an independent. As outlined below, Pumicestone MP Rick Williams was also serially accused of abusive behaviour, and his removal from the party in late October 2017 was Palaszczuk's catalyst for an early election. Police Minister and Bundamba MP Jo-Ann Miller also courted controversy in 2015 when the Parliamentary Ethics Committee found she had engaged in 'reckless conduct' after falsely signing a document affirming the disposal of confidential papers, and for allegedly contacting a witness involved in the investigation of Rick Williams. Miller resigned from Cabinet and thereafter exercised considerable independence, including aggressively questioning Labor colleagues during Budget Estimates hearings. By the end of 2015, Cairns MP Rob Pyne had fallen out with his Left faction and, by early 2016, he too had resigned from the party to sit as an independent.

Labor's reduction in numbers in the Legislative Assembly saw the government require Katter's Australian Party (KAP) support on parliamentary votes, and the government suffered its first significant defeat in the parliament when Labor refused to support KAP's Sugar Industry (Real Choice in Marketing) Amendment Bill 2015 in December 2015. Labor's second major defeat arrived in 2016 when its Vegetation Management (Reinstatement) and Other Legislation Amendment Bill, or 'Tree-Clearing' Bill, was rejected. Labor enjoyed a significant victory in February 2016, however, when KAP supported its Tackling Alcohol-Fuelled Violence Legislation Amendment Bill, designed to curb alcohol-fuelled violence. Anti-violence campaigners were shocked when, in early 2017, removed Palaszczuk 'lock-out' provisions - to be replaced with patron identification scanners - even before their commencement (Vogler 2017e). 
Much of the term saw the government defend a relatively weak economic record. Unemployment hovered around 6 per cent ${ }^{7}$ and state debt remained Australia's highest at around $\$ 80$ billion. The opposition and business community also criticised the fact that 20,000 of the 120,000 jobs Labor claimed to have created since 2015 had emerged in the public service (Caldwell 2017b; Carmingnani and Healy 2017). However, improving tourism and agricultural sectors - Queensland enjoyed a 'chick pea' boom (Williams 2017a) - helped Treasurer Curtis Pitt to deliver three successive budget surpluses that, with an improving debt-to-revenue ratio, allowed Moody's to remove the 'negative watch' from Queensland's $\mathrm{AA}^{+}$ credit rating. By late 2016, Queensland was enjoying a nascent economic recovery, and the confidence of business leaders - hitherto impatient with Palaszczuk's slow reform - gradually returned (Syvret 2016). This recovery was hindered, however, by Category 4 Cyclone Debbie in North Queensland in early 2017 that caused $\$ 2.4$ billion in damage. Fortuitously for Labor, a Galaxy opinion poll found 76 per cent of all voters - and 65 per cent of LNP supporters - approved of Palaszczuk's crisis management (Williams 2017a).

The fact coal royalties remained relatively subdued explains the major parties' enthusiasm for a $\$ 21$ billion Adani coal mine in the Galilee Basin - initially promised to create 10,000 jobs, but potentially far fewer (Chang 2017) - that framed much of the 2017 campaign. The Treasurer, however, suffered enormous criticism for moving $\$ 4.1$ billion of state debt onto government-owned enterprises (GOE) accounts and repaying debt from funds 'repatriated' from the state public service superannuation fund (Williams 2016). Moreover, Labor stood accused of favouritism to trade unions in industrial relations, including around employment in Queensland Rail - the focus of one of two major policy failures to dominate the news media. In what would become the 'Rail Fail' saga, Transport Minister Stirling Hinchliffe resigned in early 2017 after newly acquired trains were found to suffer major design faults; there were also too few staff to drive them (Williams $2017 \mathrm{~b}$ ). The second major crisis emerged in the area of child safety after a number of deaths of children in care (Walker 2017b). Other ministers also embarrassed the government. In late 2016, Agriculture Minister Leanne Donaldson resigned over unpaid council rates (Williams 2017b) while, in 2017, Main Roads Minister Mark Bailey stood aside after referral to the Crime and Corruption Commission (CCC) over inappropriate email use (Elks 2017a).

In a coup for Pauline Hanson, Buderim MP Steve Dickson deserted his party to join PHON in January 2017; other former LNP MPs soon became PHON candidates. But this fillip was overshadowed by a litany of gaffes throughout 2017 that arguably suppressed the party's appeal. Soon after its 2016 federal double dissolution success, PHON's internal divisions were exposed when West Australian Senator Rod Culleton fell out with Hanson over Culleton's undischarged bankruptcy. ${ }^{8}$ Pauline Hanson's chief of staff James Ashby also courted controversy when former PHON officials and candidates accused him of autocratic behaviour and conflicts of interest (Lewis 2017b; Scott 2017). It was alleged that Ashby insisted PHON candidates purchase campaign packages from a printing business he owned (Killoran 2017b). A number of PHON state candidates were then disendorsed in early 2017 for offensive social media use (Williams 2017b). PHON was further chastened by a March 2017 West Australian state election result that fell well short of expectations - a result largely attributed to an unpopular preference exchange with the Liberals 
that later shaped PHON's Queensland preference strategy (Walker 2017c). Hanson was also criticised for suggesting Queensland could subsidise Western Australia's low GST receipts, but more serious condemnation came when Hanson, on the ABC TV Insiders program, expressed scepticism about childhood vaccinations and praised Russian President Vladimir Putin - long suspected of involvement in the 2015 shooting down of Malaysian Airlines flight MH17 (Gartrell 2017). In April, the ABC's Four Corners program alleged Hanson and Ashby failed to disclose the donation of a \$106,000 light aircraft (Knott 2017) then, in May, leaked taped conversations implying Ashby wanted to 'make money' from the Australian Electoral Commission (Hunter 2017). Hanson was again reproached in June for insisting autistic children be removed from mainstream schools and, in August, attracted perhaps her strongest praise and deepest condemnation for wearing a full burqa into the Senate chamber - a stunt she said highlighted Australians' concerns about 'national security' (Bickers and Harris 2017).

The LNP suffered its own problems, and by early 2016 MPs' confidence in leader Lawrence Springborg's ability to arrest Palaszczuk's popularity had plummeted. In May, Tim Nicholls (Clayfield) and Tim Mander (Everton) challenged Springborg and, in a twenty-two to nineteen vote (second round) result, Nicholls defeated Springborg, with Deb Frecklington (Nanango) elected deputy leader unopposed (Williams 2016). As detailed below, however, Nicholls' leadership failed to substantially improve the LNP's public standing, and it was widely speculated that Nicholls' role in the unpopular Newman government debilitated the LNP's 2017 campaign (Grattan 2017; Peel, Walker and Elks 2017). Moreover, just months before the election, the Electoral Commission of Queensland (ECQ) took the LNP to court to force the party to reveal the source of $\$ 100,000$ in undisclosed political donations (Layt 2017b). The LNP's prospects were dealt a blow in 2016 when LNP Attorney-General George Brandis - unaware that an LNP conference microphone was 'open' - described the Nicholls opposition as 'very, very mediocre' (Mcllroy 2016). The Greens enjoyed a relatively high profile during the triennium and, buoyed by the 2016 election of the party's first Brisbane City Councillor in the inner-city Gabba ward, campaigned heavily against the Adani mine. Indeed, long before the parliament's dissolution, The Greens declared the seat of South Brisbane, held by Labor Deputy Premier Jackie Trad, its primary target (Crowe 2017).

The parliament also saw major structural change. In March 2016, 52.96 per cent of Queenslanders supported a referendum to commence fixed four-year parliamentary terms, ${ }^{9}$ and in April the Legislative Assembly increased to 93 seats (Williams 2016). Labor was later criticised for attaching to the Electoral (Improving Representation) and Other Legislation Bill a return to CPV - a model replaced in 1991 by optional preferential voting. ${ }^{10}$ The expanded parliament and subsequent redistribution saw the most significant changes to the number, geography and nomenclature of districts since 1985. While North Queensland saw Dalrymple abolished, six new seats were created in the south-east. In Brisbane, Mt Coot-tha was abolished, while Albert on the northern Gold Coast was also removed and replaced by Macalister, Bonney and Theodore. The Sunshine Coast received the new seats of Ninderry and Bancroft. Just four seats remain with areas exceeding $100,000 \mathrm{~km}^{2}$, making them exempt from the 'one vote, one value' principle. Three LNP seats (Mansfield, Mt Ommaney and Burdekin) became nominally Labor while Labor's Pumicestone 


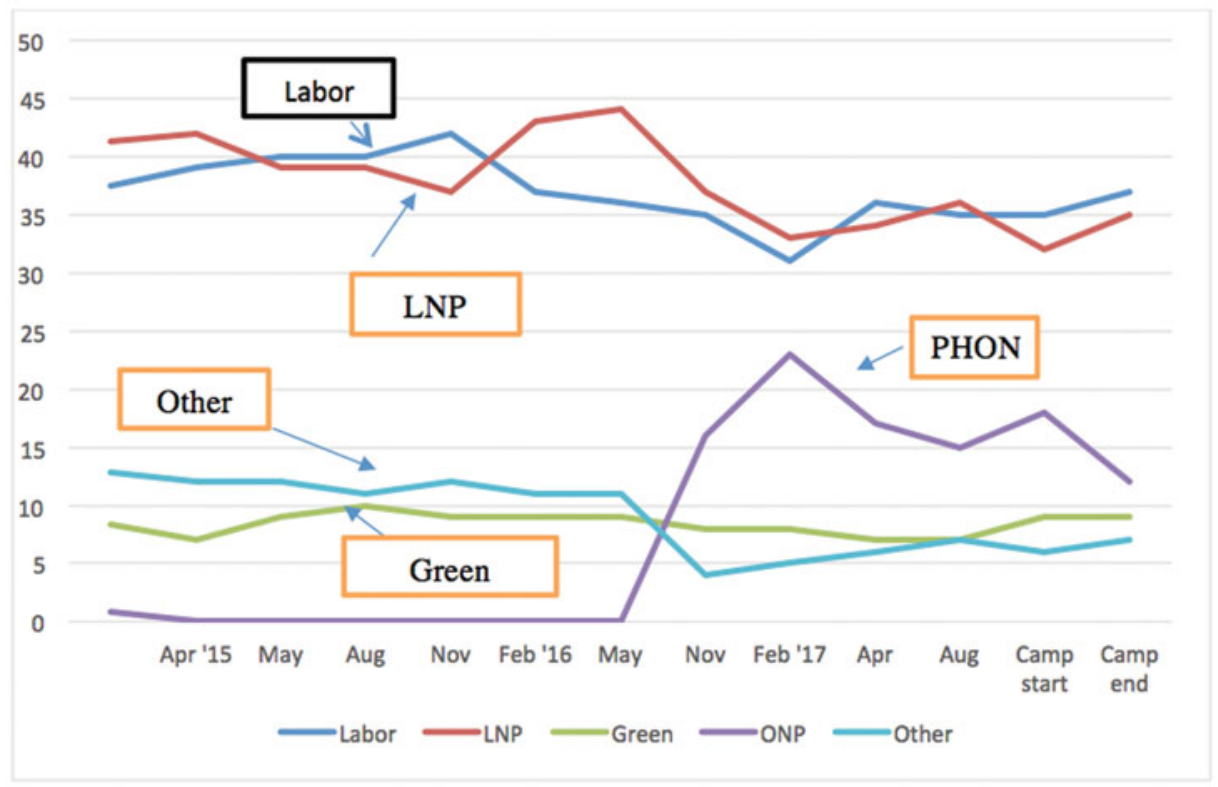

Figure 1

(Colour online) Primary vote by party, Galaxy poll, 2015-17.

Source: Galaxy Research (2017).

became nominally LNP. On 2015 vote returns, new boundaries meant Labor would enter the 2017 campaign with 48 seats (Green 2017).

\section{Opinion polls}

The questions of how Palaszczuk's minority government remained competitive, and why Nicholls' accession to the LNP leadership had failed to gain traction, were often asked (Williams 2017c). Neither Labor nor the LNP attracted a primary vote above 45 per cent (see Figure 1). The LNP's zenith came in May 2016 - immediately after Nicholls' election - while Labor peaked at 42 per cent in November 2015. The Greens' nadir, of 7 per cent, arrived in April 2015, and its zenith of 10 per cent came four months later. Because Galaxy, until May 2017, included PHON support in its 'Other' total, the 'Other' vote declined to 4 per cent in November 2016. PHON's support peaked at 23 points in February 2017 before commencing a long series of gaffes. Galaxy, polling in only the 61 seats PHON contested, found the party's support collapsed six points, from 18 to 12 per cent, during the campaign.

Newspoll found similar trends in the major parties' 2PP vote. ${ }^{11}$ Where Labor reached a zenith of 53 per cent $2 \mathrm{PP}$ (to the LNP's 47 per cent) on two occasions (August-September 2015 and July-September 2016), the parties reached their most competitive point in May-June 2015 at 51 to 49 per cent in Labor's favour. Where Labor and the LNP began the campaign at 52 to 48 per cent respectively, the campaign ended with Labor attracting 52.5 per cent $2 \mathrm{PP}$ and the LNP 47.5 per cent (Newspoll 2017). 


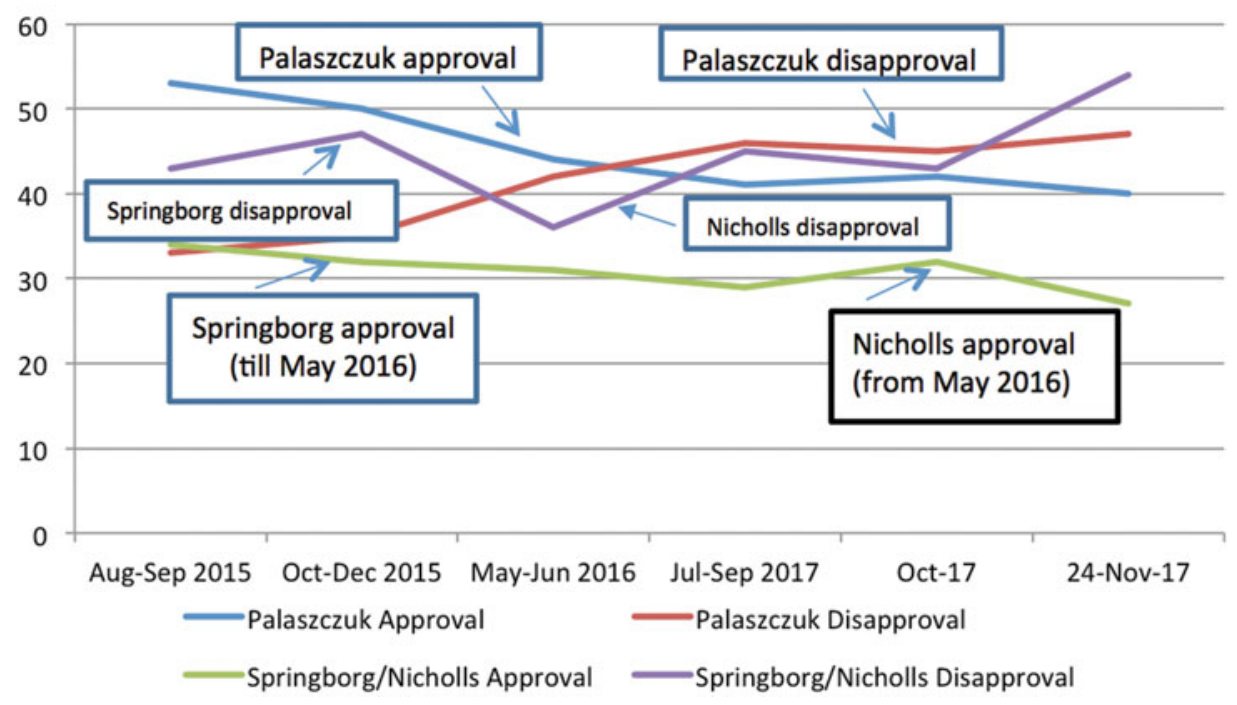

Figure 2

(Colour online) Labor and LNP leaders' approval/disapproval ratings, Newspoll 2015-17. Source: Newspoll (2015-17).

As Figure 2 reveals, Newspoll found a steady decline in Palaszczuk's approval rating over the triennium, and a commensurate rise in her disapproval rating. Indeed, Palaszczuk fell from a net ${ }^{12}$ high of 20 points in mid-2015 to a net low of negative seven points on election eve. By contrast, Lawrence Springborg suffered a net negative of fifteen points in late 2015 before his removal in May 2016, an event that saw Nicholls assume the opposition leadership with a net negative rating of five points. At no point during the triennium did Nicholls enjoy a positive net approval rating, and he closed his campaign with a net negative of thirty-seven. Similarly, Nicholls — and Springborg before him — trailed Palaszczuk as 'preferred premier' for the entire period. Where Nicholls remained around ten points behind Palaszczuk for much of 2016 and 2017, the opposition leader ended the campaign fourteen points behind the premier (Newspoll 2017). It can be concluded from these data that Palaszczuk's popularity, relative to that of Nicholls, was a key factor in Labor's re-election.

\section{Voter expectations}

An online focus group of 311 respondents, conducted by political analyst Graham Young in early November, found 41 per cent hoped for a Labor victory, 39 per cent for an LNP majority government and 17 per cent for another hung parliament. Paradoxically, 52 per cent believed a hung parliament would be the most likely outcome. Critically, the poll also found just 37 per cent believed the Palaszczuk government deserved re-election and 53 per cent believed it did not. This suggests swinging voters' support for Labor on 25 November was grudging. Equally, only 23 per cent of all respondents - and just 50 per cent of LNP supporters - believed the LNP deserved to win (Walker 2017d). 


\begin{tabular}{lll}
\hline \multicolumn{2}{l}{ Table 1 Voters' issue salience (\%), Galaxy opinion poll, November 2017} \\
\hline Issue & South-East Queensland & State \\
\hline Jobs & 29 & 40 \\
Stable government & 29 & 28 \\
Health & 32 & 31 \\
Leadership & 24 & 27 \\
Power prices & 19 & 29 \\
Roads & 24 & 19 \\
Economy / Debt & 23 & 20 \\
Adani & 16 & 17 \\
\hline
\end{tabular}

Source: Marszalek (2017).

\section{Issues}

A November Galaxy poll found eight issues dominated voters' concerns, with the state divided between Brisbane and the regions as to the salience ${ }^{13}$ of those issues.

As Table 1 indicates, 'jobs', 'stable government', 'health' and 'leadership' enjoyed the highest salience among voters across the state and in the south-east. While power prices were more important for regional voters, roads were more salient among Brisbane residents. Interestingly, 'economy/debt' - an issue on which centre-right parties traditionally rate well - rated comparatively lowly, as did the ostensibly high-profile 'Adani' issue. These findings suggest Labor's creation of 120,000 jobs, its commitment to stable majority government, Palaszczuk's resolute leadership in recommitting to 'no deals' with minor parties and health policy management - a strength of centre-left parties (Klüver and Sagarzazu 2016, p. 383) combined to create a perception that Labor was better placed to deliver stability and growth.

\section{Rationale for an early election}

Media speculation about an early state poll began soon after the January 2015 election, and only grew over the next 30 months as the government suffered political crises. Speculation intensified from January 2017 - after Palaszczuk diluted her own government's alcohol-management laws - and soared after the June budget (Williams 2017c). But the timing of any election was partially dependent upon the finalisation of the electoral redistribution described above. ${ }^{14}$ The government also insisted that no election could be called before 30 June when electoral rolls would be updated. It seemed more plausible, however, that the government was awaiting the outcome of a CCC investigation into Mark Bailey's private email use. Election speculation therefore peaked after the CCC cleared Bailey in late September, but in mid-October the Premier said it was her 'intention' the parliament should resume ${ }^{15}$ and insisted the election - due in late January but deferrable until 5 May - would be in 2018 unless 'extraordinary' events intervened. Following the ill-health retirement of Rockhampton MP Bill Byrne, Palaszczuk secured those 'extraordinary' circumstances when the party disendorsed Pumicestone Labor MP Rick Williams on 27 October, after numerous allegations of brusque treatment of constituents (Vogler and Wardill 2017). Yet, with the major parties each reduced to 
41 seats, ${ }^{16}$ and with a looming election all but confirmed, Palaszczuk still deflected speculation and said she would spend Sunday - National Grandparents Day with her grandmother. Palaszczuk indeed visited her grandmother on the morning of 29 October, then at 11.00 a.m. met with Acting Governor Catherine Holmes to advise writs be issued for an election on 25 November: a 28-day campaign, two days longer than the legal minimum so often the Queensland norm.

Palaszczuk later arrived at the Darra Bowls Club in the marginal seat of $\mathrm{Mt}$ Ommaney where, at a media conference, she rationalised an early election as an opportunity 'to give business and industry in our great state the certainty they need' (O’Brien 2017). 'The choice facing Queenslanders is simple,' Palaszczuk said. 'A stable Labor government with a solid record and a clear plan focused on Queensland's future or a cobbled-together LNP-One Nation government that will cut frontline services, sack frontline staff and sell our electricity assets' (Elks 2017b). But Palaszczuk was interrupted by anti-Adani coal mine protestors clamouring to the dais. Adani protestors also attended LNP leader Tim Nicholls' first campaign event, where Electrical Trades Union members also protested any potential privatisation policy. But Nicholls struck a larger problem when former LNP Premier Campbell Newman warned - despite Nicholls ruling out any coalition with One Nation - that the LNP could not form government without PHON support (O’Brien 2017). PHON's first day saw state leader and Buderim MP Steve Dickson address the media while national leader Pauline Hanson was overseas on parliamentary business. Hanson later described Palaszczuk's election timing as 'cowardly' (Walker 2017a). Dickson immediately castigated both Labor and the LNP over the 'Safe Schools' program that, Dickson insisted, demanded boys 'dress up in dresses' (Education HQ 2017). Indeed, it can be argued that intemperate rhetoric on this issue worked against PHON's ingratiation with swinging voters. By early November, the major parties had settled into their campaign slogans: where Labor warned voters of Nicholls' 'cuts and [LNP-PHON] chaos', the LNP described Labor as a party of 'fear, smear and no idea' (Peel 2017).

\section{The campaign proper}

\section{Week 1: 29 October to 4 November}

The campaign's first full day saw Palaszczuk fly to the regions, where Queensland elections are typically won and lost. In Airlie Beach, the Premier's first media conference was interrupted by an anti-Adani protestor who appeared to lunge at Palaszczuk. The premier conceded that she was fearful and called for 'respect' (Vogler 2017b). LNP leader Tim Nicholls - locked in South-East Queensland due to an inability to secure a charter flight — 'front-ended' his campaign in the first week (to circumvent the growing number of pre-poll voters) with major policy announcements, including the creation of 500,000 jobs over ten years; the construction of a north Queensland coal-fired power station; overseeing a $\$ 1.3$ billion 'drought-proofing' dam plan; raising the payroll tax threshold for small business; and imposing a youth curfew in north Queensland to combat juvenile crime (Ludlow 2017a). By contrast, Labor spruiked its economic credentials by reminding voters that state debt had been reduced by $\$ 600$ million earned from GOEs the Newman government planned to sell. Nicholls replied that his party's 
strategy was merely to stabilise debt - arguably the only option, given its newfound opposition to privatisation.

Labor then received two campaign fillips. First, the CCC cleared Police Minister Mark Ryan over allegations he had 'interfered' in a parole decision to prevent a murdered man's family learning of the killer's release (Layt 2017a; Courier-Mail 2017a). Second, Cook MP Billy Gordon announced his retirement, a move that would ease Labor's return to Cape York. Pumicestone MP Rick Williams then threatened to release taped conversations he said proved the premier begged him to remain in politics, and later released an edited conversation where Palaszczuk had told Williams he was 'doing a good job' (Akers 2017b). More bad news arrived for Labor when popular child safety campaigner Hetty Johnston announced her candidacy for the new, and nominally Labor, seat of Macalister. But Labor faced greater embarrassment after the leaking of a Department of Energy report (delivered in February but not publicly released and, according to Palaszczuk, left unread by Cabinet ministers), which indicated a new 'ultra-supercritical' coal-fired power station in north Queensland would reduce emissions and secure supply while remaining profitable, despite Labor arguing new coal-fired stations 'did not stack up' (McKenna 2017; Wardill 2017a).

Labor's most critical event of the first week arrived with Palaszczuk's media conference late on 3 November, where the Premier announced her intention to use Queensland's veto to block a $\$ 900$ million loan to Adani from the Commonwealth Northern Australia Infrastructure Facility (NAIF). Palaszczuk's initial rationale for exceeding the Integrity Commissioner's advice - to merely remove herself from the loan decision-making process - and to veto the loan was to quell rumours of a conflict of interest given her life-partner, Shaun Drabsch, had worked on the NAIF application in his employment with PricewaterhouseCoopers (Viellaris and Vogler 2017). Emphasising that she had no knowledge of Drabsch's Adani link, Palaszczuk added, 'Let me make it absolutely clear. I guard my integrity most dearly. I want to put beyond any doubt that this is nothing more than an LNP smear' (Caldwell 2017a). Within days, however, Palaszczuk's rationale shifted to a reminder that Labor in 2015 had pledged no public money for Adani. When it later emerged the party had conducted focus group research that found voters, even in regional Queensland, opposed any Adani loan, it was clear Palaszczuk had secured at least some political advantage: from this point, environmental protestors veered away from Labor's campaign and towards the LNP's (Schliebs, Peel and Elks 2017). For their part, The Greens promised one-dollar public transport fares and four new public holidays, including one around State of Origin rugby league matches (Killoran 2017a). By the close of nominations on 3 November, some 3.230 million voters were enrolled, an increase of 249,000 since 2015 (ECQ 2017).

\section{Week 2: 5-11 November}

The second week began with LNP Senator Matt Canavan alleging a 'domestic' between Palaszczuk and her 'boyfriend' forced the Adani loan veto (Peel 2017). Nicholls refused to condone Canavan's words, and instead engaged in voter-friendly stunts such as riding a MovieWorld rollercoaster. Nicholls also pledged expenditure for domestic violence, ice addiction and upgrades for Gold Coast M1 on-ramps. Palaszczuk's fortunes appeared to improve from this point as the news media subjected Nicholls to closer scrutiny. He was again forced to rule out Newman-style 
cuts to the public service and, while former prime minister Tony Abbott's offer to campaign for Nicholls was rejected, federal opposition leader Bill Shorten happily campaigned alongside the premier. Palaszczuk then appeared to resonate with voters in Maryborough — Labor would record a 19.4 per cent primary vote swing there - when she pledged that Queensland trains would be built locally and not in the LNP's choice of Mumbai (Schliebs, Peel and Elks 2017). On Melbourne Cup Day, Palaszczuk also promised to boost regional racing and, later in Logan, she pledged local hospital upgrades. The premier later appeared genuinely shocked when popular Rockhampton Mayor Margaret Strelow — recently defeated in Labor preselection to contest Rockhampton despite Palaszczuk's personal endorsement - announced she would contest the seat as an independent (Smith 2017).

The week also saw PHON leader Pauline Hanson return to Australia and enter a campaign she said would produce a result 'bigger than 1998' (Marszalek and Akers 2017a). Anecdotally, many Queenslanders appeared unaware Senator Hanson was not - and could not be - a candidate in this election (Marszalek and Akers 2017b). After announcing a preference deal with KAP - her only formal agreement of the campaign - Hanson launched her 'Battler Bus': a modest vehicle boarded by PHON leaders and journalists Hanson warned would be removed if they 'sensationalised' stories (Motherwell 2017). In what would become a metaphor for PHON's campaign, the bus soon broke down, but not before it was revealed that its manufacturer outsourced labour to Malaysia (Trott 2017). PHON soon suffered far more significant campaign turning points. The first came mid-week when Hanson failed to condemn a white nationalist group for its racist attack on (the now former) Labor Senator Sam Dastyari. While Liberal Prime Minister Malcolm Turnbull denounced the abuse, Hanson labelled Dastyari a 'smart arse' and a 'pip-squeak' (Jones 2017). Hanson's second, and arguably more damaging, turning point arrived in Townsville when journalists questioned her Thuringowa candidate, Mark Thornton, over a sex shop web page (under Thornton's ownership) that opined 'good sex should be in the grey area between tickle fight and domestic violence.' A furious Hanson said any community outrage was merely 'political correctness gone mad' (Akers 2017a). In an attempt to deflect criticism, Hanson pivoted to the 'Safe Schools' program that, she alleged, teaches children 'how to strap on a dildo [and] how to masturbate' (Akers 2017a). State leader Steve Dickson repeated the 'Safe Schools' allegation a day later, then apologised after teachers denied the claim and after Palaszczuk said she was 'absolutely lost for words that someone would dare say such things that are simply and utterly not true' (Courier-Mail 2017b).

Voters appeared to perceive the Hanson and Dickson comments as political overreach. But a critical turning point for the LNP dwarfed even those events when, late on Friday, the LNP state executive released the party's long-awaited preference decision that would shape numerous regional outcomes. Given that LNP state president Gary Spence had indicated, as early as August 2016, that his party would preference PHON favourably (O'Brien and Briggs 2016), few were surprised when the executive formalised the decision just two days before the commencement of pre-poll voting. Indeed, while the LNP preferenced all Greens candidates last, it also placed PHON ahead of Labor in 49 of the 61 seats PHON contested (Schliebs, Peel and Elks 2017). ${ }^{17}$ By close of nominations on 7 November, 453 candidates had nominated - twenty more than in 2015 (ECQ 2017). 


\section{Week 3: 12-18 November}

Arguably the most significant turning point for PHON arrived on 13 November, when Queensland Senator Fraser Anning resigned from PHON to sit as an independent just an hour after being sworn in to replace Malcolm Roberts, now disqualified over dual citizenship. Anning's resignation apparently 'follow[ed] weeks of internal party tensions and revelations Senator Hanson had wanted [Anning] to resign to allow for the return of Malcolm Roberts' (Lewis 2017a). Given that a Galaxy poll found 41 per cent of Queenslanders were less likely to support PHON after Anning's resignation, and just 7 per cent were more likely - a net deficit of 37 points (Wardill 2017b) — swinging voters appear to have conflated the LNP with PHON, and agreed that a vote for either party would produce instability (Akers 2017c). Both Palaszczuk and Nicholls returned to regional Queensland, where there was a discernible lift in the Premier's demeanour and a commensurate decline in Nicholls'. After struggling with questions around his youth detention policy, Nicholls appeared embarrassed by his party's preference decision and continued to avoid journalists' questions around accepting PHON support for any minority LNP government. Palaszczuk, by contrast, robustly pledged 'no deals' - a promise some received sceptically after a similar commitment in 2015 was broken when Labor accepted the support of Nicklin Independent Peter Wellington (Akers 2017c). Labor strategists, however, were troubled by a Galaxy poll that indicated deputy premier Jackie Trad would lose her South Brisbane seat to The Greens, 49 to 51 per cent (Wardill 2017c). There was also speculation — denied by Palaszczuk - that the premier had fallen out with Townsville Mayor Jenny Hill over the Adani loan veto (Ludlow 2017b). Finally, the LNP would have been disappointed by Nicholls' performance at the campaign's only leaders' debate (which included PHON's Dickson but not The Greens) on 16 November. Contrasting with Palaszczuk's more confident pitch, the opposition leader was heckled when he again skirted the question of PHON support, then conceded the LNP would 'accept the will of the people [and] work with the parliament that the people of Queensland provide' (Akers 2017d). Sixty per cent of the 100 undecided voters said they would now vote Labor, with just 12 per cent supporting the LNP and 10 per cent PHON, leaving 18 per cent undecided (Marszalek and Vogler 2017). To counter, Nicholls - who had previously run a positive campaign - increased his personal attacks on the premier where, at a media conference, he called Palaszczuk a 'liar' on around 20 occasions (Akers 2017c).

\section{Week 4: 19-25 November}

The final week saw both major parties officially launch their campaigns on 19 November. Labor launched at Surfers Paradise where boxing champion Jeff Horn introduced the premier (Ludlow 2017c). Labor then pledged an extension of the \$20,000 First Home Owners Grant, an extra \$20 million to attract film and television projects and $\$ 107$ million to employ 'quality teachers' (Vogler 2017c). The LNP's campaign was simultaneously launched in inner Brisbane by Prime Minister Malcolm Turnbull, who described the Palaszczuk government as a 'lazy, donothing, Green-left Labor' administration (Peel, Walker and Elks 2017). Nicholls again distanced himself from the Newman years, arguing that, 'My team and I are different' (Weston 2017). A failure to agree on schedules meant the leaders 
addressed the Queensland Media Club on separate days. On Tuesday, a seemingly nervous Nicholls pitched directly to voters rather than the media and pressure group leaders in attendance (mysunshinecoast.com 2017); on election eve, a more polished Palaszczuk revisited her 'cuts and chaos' theme (Brisbane Times 2017). The week also saw Pauline Hanson and Bundamba Labor MP Jo-Ann Miller filmed embracing at a pre-poll station (Vogler 2017a). Palaszczuk was angry at what was likely a prearranged meeting designed to enhance the standing of both Hanson and Miller among working-class voters while undermining Labor's mantra of 'no deals' (Madigan, Akers and Vogler 2017). While Adani protestors disrupted an LNP breakfast mid-week, Hanson labelled Palaszczuk a 'spoilt brat' and told Nicholls to 'grow up' (Australian 2017). Each major party released its costings two days before polling day. After Labor revealed four new wealth taxes on landowners, luxury car owners and online gambling companies that would raise almost $\$ 500$ million, Palaszczuk happily accepted a 'Robin Hood' mantle (Peel and Elks 2017). By contrast, the LNP pledged to remove $\$ 2.5$ billion from Brisbane's Cross River Rail, oversee a 'government efficiency program' to save $\$ 1.6$ billion and offer almost $\$ 1$ billion in cost of living relief. In an election only occasionally punctuated by specific spending commitments, the LNP's promises totalled $\$ 4.3$ billion while Labor's totalled \$1.6 billion (Ludlow 2017d; Robertson 2017). Despite a 'barnstorming' tour of nine electorates and a last-minute appearance by then federal Nationals leader Barnaby Joyce, Nicholls' campaign continued to falter, especially after an interview on Channel Seven's Sunrise program where he pleaded with voters to 'support your local LNP-One N ... ah ... LNP candidate' (Vogler 2017d). The campaign's final Galaxy poll bolstered Palaszczuk: Labor led the LNP after preferences 52 to 48 per cent. Indeed, the city-country divide was especially pronounced: where Labor enjoyed an eight-point lead, 54 to 46 per cent, over the LNP in South-East Queensland, the LNP enjoyed a narrower lead, 52 to 48 per cent, over Labor in the regions (Wardill 2017d). Declarations of political donations revealed that, during the campaign, the LNP received $\$ 1.463$ million, Labor $\$ 711,000$, KAP $\$ 146,000$, The Greens (from individuals only) \$78,000 and PHON (including candidate Malcolm Roberts) just \$26,000 (Tilley 2017).

\section{Results}

Table 2 reveals that Labor contained the primary swing against it to just 2.04 per cent, while winning an additional four seats with a 0.1 per cent $2 \mathrm{PP}$ swing to it. Table 2 also reveals the LNP's net loss of three seats in a 7.63 per cent negative primary swing. ${ }^{18}$ The Greens' 10 per cent vote is a slight improvement over the 2015 result and, given the campaign's environmental profile, not unexpected. Perhaps the most significant result comes in PHON's mixed fortunes. While the party won just 13.73 per cent across the state, it attracted 20.11 per cent in the 61 seats it contested. ${ }^{19}$ However, the fact that PHON won just a single district (Mirani) - far below party leaders' predictions of 20 seats (McKenna and Elks 2017) - suggests PHON failed to meet public expectations.

In the Greater Brisbane area, the LNP lost Aspley (Tracey Davis), Maiwar (Scott Emerson), Redlands (Matt McEachan) and the nominally Labor seats of Mansfield (Ian Walker) and Mt Ommaney (Tarnya Smith). Aspley and Redlands were lost largely because PHON candidates attracted significant primary vote tallies at the 
Table 2 Primary and two-party preferred (2PP) vote (\%) and seat share, Queensland election, 25 November 2017

\begin{tabular}{llllllll}
\hline & $\begin{array}{l}2017 \\
\text { Candidates } \\
\text { Party }\end{array}$ & $\begin{array}{l}2015) \\
\text { Primary } \\
\text { Vote }\end{array}$ & $\begin{array}{l}\text { Swing } \\
\text { since } \\
2015\end{array}$ & $\begin{array}{l}20172 \text { PP } \\
\text { Vote }\end{array}$ & $\begin{array}{l}\text { Swing } \\
\text { since } \\
2015\end{array}$ & $\begin{array}{l}\text { Seats } \\
\text { won }\end{array}$ & $\begin{array}{l}\text { Seats } \\
\text { change } \\
(+/-)\end{array}$ \\
\hline Labor & $93(89)$ & 35.43 & -2.04 & 51.2 & +0.1 & 48 & +4 \\
LNP & $93(89)$ & 33.69 & -7.63 & 48.8 & -0.1 & 39 & -3 \\
Greens & $93(89)$ & 10.00 & +1.57 & & & 1 & +1 \\
KAP & $10(11)$ & 2.32 & +0.39 & & & 3 & +1 \\
PHON & $61(11)$ & 13.73 & +12.81 & & & 1 & +1 \\
CR & $8(0)$ & 0.27 & +0.27 & & & 0 & 0 \\
PUP & $0(50)$ & - & -5.11 & & & - & - \\
FF & $0(28)$ & - & -1.19 & - & - & - & - \\
Other* & $95(66)$ & 4.58 & +0.95 & & & 1 & 0 \\
\hline
\end{tabular}

Source: ECQ (2017). Figures do not total 100.00 due to rounding.

*2PP figures are Kevin Bonham's estimate http://kevinbonham.blogspot.com.au/2017/12/ queensland-2017-final-results-and.html

Key: LNP = Liberal-National Party; PUP = Palmer United Party; KAP = Katter's Australian Party;

$\mathrm{FF}=$ Family First; $\mathrm{CR}=$ Civil Liberties, Consumer Rights, No Tolls; PHON = Pauline Hanson's

One Nation; Other includes independents.

expense of the LNP, and because PHON preferences leaked generously to Labor at rates of up to 50 per cent (ECQ 2017). Anecdotally, the LNP's decision to preference PHON above Labor appeared also to damage the party's credibility among small 'l' liberal Brisbane voters. Nicholls' own seat of Clayfield, for example, suffered a 4.2 per cent $2 \mathrm{PP}$ swing away from the LNP to make this formerly 'fairly safe' seat 'marginal'. ${ }^{20}$ The reasons why The Greens failed in their targeted seat of South Brisbane, and why they unexpectedly won Maiwar, can be found in the reintroduction of CPV. The LNP, finishing third in South Brisbane, directed its preferences to Labor in a decision that, while opposed by some on the LNP State Executive, ${ }^{21}$ saw Labor's Jackie Trad attract 4,461 LNP preferences and win with 53.55 per cent 2PP. Conversely, in Maiwar, Labor finished third; around 80 per cent of Labor preferences flowed to The Greens' Michael Berkman, whose primary vote was well below the LNP's Scott Emerson (ECQ, 2017). Labor also saw its first victory on the Gold Coast (Gaven) since 2009, and reclaimed Cairns and Cook. Not unexpectedly, Labor lost Pumicestone (Rick Williams) and Bundaberg (Leanne Donaldson) to the LNP, and Mirani (Jim Pearce) to PHON. The LNP recaptured Nicklin, regained Dickson's seat of Buderim and lost Noosa (Glen Elmes) to a popular independent. The results also reveal deep contrasts in voter behaviour that, in turn, support the 'two Queenslands' thesis (Holmes 1994; Williams 2004, p. 635). Where Labor repeatedly enjoyed $2 \mathrm{PP}$ swings to it in LNP seats in the south-east, the party saw commensurate swings against it in its own seats in the regions.

Queensland's fifty-sixth parliament is precariously balanced, with the LNP and Labor each defending fifteen marginal seats. While Labor boasts sixteen safe seats, the LNP holds just eleven (ECQ 2017). The election also saw a 4.34 per cent informal vote, or more than double 2015's 2.11 per cent — largely attributable to the return of CPV - and a participation rate of just 87.52 , lower than 2015 's 89.89 per 
cent (ECQ 2017). In terms of election type, the 2017 poll resembles a 'reinstating' poll in which 'the effects of short-term factors [such as asset privatisation policy] disappear, and the former patterns of party support [are] reinstated' (Jaensch 1995, p. 101).

\section{Conclusion}

Drawing on the quantitative and qualitative evidence explored above, Labor's re-election can be attributed first to voters' strong desire for stable majority government. For many swinging voters, Palaszczuk's resolute insistence that no preferences be given to PHON - and no post-election support accepted from any minor party, a strong contrast to the LNP - provided ambivalent voters with a clear pathway to stable government. Second, Labor's re-election can also be attributed to Palaszczuk's strong approval among voters relative to Nicholls'. Third, given that 'jobs' enjoyed high issue salience for voters, Labor's creation of 120,000 positions over three years was likely well received. Conversely, the LNP's dire result can be attributed first to the LNP's preference decision that conflated the LNP with a rhetorically reckless far-right party. This conflation appeared to be compounded by Nicholls' reluctance to acknowledge the post-election need for PHON support - an arrangement that voters saw as potentially unstable. Second, the loss of specific LNP seats can also be attributed to PHON attracting significant primary votes at the LNP's expense, with a large proportion of PHON preferences, under CPV, leaking to Labor. Third, the LNP's defeat can be attributed at least partially to Nicholls' former role in the Newman government, and the spectre despite Nicholls' denials - of an unpopular privatisation policy. Finally, PHON's failure to win more than a single seat can be attributed to two factors: first, the party failed to win sufficient primary votes to finish first or second in counting, and therefore could not enjoy LNP preferences. Second, in seats where PHON did finish second, Labor preferences flowed almost exclusively to the LNP. Two more conclusions can be speculated. First, Labor's re-election may spell the end of Queensland's recent electoral volatility, and see Labor resume the hegemony it has enjoyed in governing, since 1989, for 23 of the past 28 years. Second, history may yet repeat if post-election frustrations split the LNP and return it - as the Country and Progressive National Party did after its second successive defeat in 1935 - to its constituent Liberal and National Parties.

\section{Endnotes}

1 Australian Capital Territory (ACT) Liberal Chief Minister Kate Carnell won the 1995 election from opposition, and was re-elected in 1998. ACT Labor Chief Minister Rosemary Follet served two non-consecutive terms after the 1989 and 1992 elections. Northern Territory Chief Minister Clare Martin won the 2001 election from opposition, and was re-elected in 2005.

2 Ronan Lee, elected as a Labor MP (Indooroopilly) in 2001, 2004 and 2006, sat as a Greens MP from 2008 and lost to the LNP in 2009.

3 William Kidston (Kidston Party) saw his minority government returned at the 1907 election, albeit with fewer seats.

4 Campbell Newman's Liberal-National Party won 78 of the Legislative Assembly's 89 seats (or 88 per cent of the chamber) with 49.66 per cent primary vote, and 62.8 per cent $2 \mathrm{PP}$. 
5 The LNP between 2012 and 2017 lost 15.96 per cent primary vote support.

6 NSW Labor Premier Kristina Keneally and Deputy Premier Carmel Tebbutt comprised Australia's first all-female leadership team, 2009-11.

7 Unemployment reached 6.7 per cent in early 2017 — the highest in Australia — with regional and youth rates higher still.

8 The High Court removed Culleton from the Senate in February 2017.

9 The 'Yes' vote won around 70 of the parliament's 89 districts.

10 ABC psephologist Antony Green calculated Labor would have won nine extra seats, and majority government, under CPV in 2015 (Wardill 2016).

11 Newspoll applied 2015 preference allocations to voters' primary voting intentions, 2015-17.

12 Net approval rating calculated by subtracting 'disapproval' from 'approval' ratings.

13 See Repass (1971) for a discussion of issue salience.

14 Had Palaszczuk called the poll before 26 May 2017 - the redistribution's finalisation the campaign would have been on old boundaries in 89 seats; after that date, the election would necessarily be on 93 new boundaries. Palaszczuk had pledged as early as late May to take the latter option.

15 The Legislative Assembly was recalled on 24, 25 and 26 October.

16 Two Katter's Australian Party MPs, four independents and a single PHON MP comprised the cross-benches.

17 The LNP preferenced Labor ahead of PHON in Stretton, Toohey, Thuringowa, Logan, Hervey Bay, Mudgeeraba, Buderim and Nicklin, and ran 'split tickets' in Coomera, Theodore, Lockyer and Scenic Rim.

18 The LNP lost 15.96 per cent primary vote support between 2012 and 2017.

19 My calculations.

20 Marginal $=0.1$ to 4.9 per cent; Fairly Safe $=5.0$ to 9.9 per cent; Safe $=>10.0$ per cent.

21 Personal communication with the author.

\section{References}

Akers, T. 2017a. 'Fifty shades of red'. Courier-Mail, 11 November, p. 9.

Akers, T. 2017b. 'Dumped MP plays tale of the tape'. Courier-Mail, 21 November, p. 8.

Akers, T. 2017c. 'Gloves off and rivals hit out'. Courier-Mail, 19 November, p. 5.

Akers, T. 2017d. 'Nicholls admits a deal may be done'. Courier-Mail, 18 November, p. 11.

Australian 2017. 'Queensland decides — on the trail day 25', 23 November, p. 8.

Bickers, C. and Harris, R. 2017. 'Pauline Hanson wears a burqa in the Senate'. CourierMail, 17 August, http://www.couriermail.com.au/news/national/pauline-hansonwears-a-burqa-in-the-senate/news-story/431d3e 825 ede1d7807a 5 e2ab3bf1a2e0, accessed 20 November 2017.

Brisbane Times 2017. 'Poll call: Queensland election live coverage', 24 November, https://www.brisbanetimes.com.au/queensland-election-2017/poll-call-queenslandelection-live-coverage-november-24-2017-20171124-gzrywp.html, accessed 26 November 2017. 
Caldwell, F. 2017a. 'Premier to veto Adani loan following alleged LNP "smear" campaign'. Daily Advertiser, 3 November, http://www.dailyadvertiser.com.au/story/ 5034119/premier-to-veto-adani-loan-following-alleged-lnp-smear-campaign/?cs=7, accessed 20 November 2017.

Caldwell, F. 2017b. 'Queensland public service expands by 20,000 jobs since 2015 election'. Brisbane Times, 26 October, https:/www.brisbanetimes.com. $\mathrm{au} /$ politics/queensland/more-than-1600-public-sector-workers-hired-in-threemonths-20171026-p4ywnt.html.

Carmingnani, F. and Healy, J. 2017. 'FactCheck: Has Queensland Labor created “more than four times" as many jobs as the LNP?' The Conversation, 16 November, https://theconversation.com/factcheck-has-queensland-labor-created-more-thanfour-times-as-many-jobs-as-the-lnp-87315.

Chang, C. 2017. 'The hunt for Adani's 10,000 jobs brings up "zero results"'. News.com.au, 27 September, http:/www.news.com.au/finance/business/mining/thehunt-for-adanis-10000-jobs-brings-up-zero-results/news-story/ 7532705440f71254b658b320d91ed02e.

Courier-Mail 2017a. 'Police Minister Mark Ryan cleared of corruption allegations', 1 November, http://www.couriermail.com.au/news/queensland/policeminister-mark-ryan-cleared-of-corruption-allegations/news-story/ $9 \mathrm{~b} 22 \mathrm{~b} 26352 \mathrm{~cd} 67 \mathrm{fa} 4 \mathrm{~b} 88416 \mathrm{cc} 089 \mathrm{e} 534$

Courier-Mail 2017b. 'Dickson: No more dildos in classroom', 12 November, p. 9.

Crowe, D. 2017. 'Greens to target Jackie Trad's seat over Adani mine', The Australian, 31 May, https:/www.theaustralian.com.au/national-affairs/state-politics/ greens-to-target-jackie-trads-seat-over-adani-mine/news-story/ 5ed5aec6ccf74ade764c18295daefb69.

Egan, G. 2017. 'Newman's ghost will still haunt Nicholls', Cairns Post, 30 October, p. 6.

Education, HQ 2017. 'One Nation leader blasts Safe Schools', 30 October, https://au.educationhq.com/news/43719/one-nation-leader-blasts-safe-schools/\#.

Electoral Commission of Queensland (ECQ) 2017. '2017 state general election: Election summary', https://results.ecq.qld.gov.au/elections/state/ state2017/results/summary.html.

Elks, S. 2017a. 'Minister met union over EBA'. The Australian, 16 October, p. 9.

Elks, S. 2017b. 'Climate blow: Premier ambushed over Adani', The Australian, 30 October, p. 6.

Galaxy Research (2017). 'Polling', http://www.galaxyresearch.com.au/polling.

Gartrell, A. 2017. 'Pauline Hanson blasts Muslims, praises Putin, questions vaccines in ABC interview', Sydney Morning Herald, 5 March, http://www.smh.com.au/federal-politics/political-news/pauline-hanson-blastsmuslims-praises-putin-questions-vaccines-in-abc-interview-20170305-guqxrd.html.

Grattan, M. 2017. 'Undecided Queensland voters disillusioned with Palaszczuk, suspicious of Nicholls', The Conversation, 12 November, https://theconversation. com/undecided-queensland-voters-disillusioned-with-palaszczuk-suspicious-ofnicholls-87321.

Green, A. 2017. '2017 Queensland State Redistribution'. ABC News, n.d., www.abc.net.au/news/elections/qld-redistribution-2017. 
Holmes, J. 1994. 'Coast versus inland: Two different Queenslands?' Queensland Review $1(1), 14-27$.

Hunter, F. 2017. 'Hanson defends staffer over “poor choice of words”'. Sydney Morning Herald, 23 May, p. 6.

Jones, Q. 2017. 'Dastyari using racist attack to “sell book" says Hanson'. Queensland Times, 9 November, https://www.qt.com.au/news/sam-dastyari-raceattack-stunt-pauline-hanson/3260865.

Jaensch, D. 1995. Election! How and why Australia votes. Sydney: Allen \& Unwin.

Killoran, M. 2017a. 'Standing in a green shadow'. Courier-Mail, 8 November, p. 10.

Killoran, M. 2017b. 'War of words to legal fight'. Courier-Mail, 11 December, p. 16.

Klüver, H. and Sagarzazu, I. 2016. 'Setting the agenda or responding to voters? Political parties, voters and issue attention'. West European Politics 39(2), 380-98.

Knott, M. 2017. 'High flyer: AEC to investigate One Nation over plane claims'. Sydney Morning Herald, 5 April, p. 9.

Layt, S. 2017a. 'LNP refers Mark Ryan to CCC over parole claim'. Brisbane Times, 17 August, https:/www.brisbanetimes.com.au/national/ queensland/lnp-refers-mark-ryan-to-ccc-over-parole-claim-20170817-gxysb3.html.

Layt, S. 2017b. 'LNP slammed over political donations fight'. Brisbane Times, 22 August, https://www.brisbanetimes.com.au/national/queensland/lnp-slammed-overpolitical-donations-fight-20170822-gy1x1s.html.

Lewis, R. 2017a. 'One Nation's newest senator Fraser Anning abandons Pauline Hanson'. Australian. 13 November. https:/www.theaustralian.com.au/national-affairs/ one-nations-newest-senator-fraser-anning-abandons-pauline-hanson/news-story/ 58ab1e6d3b52f9866bc85d204b5b7c0c.

Lewis, R. 2017b. 'Hanson aide accused of 'bullying, threatening' crossbench staffer', The Australian. 1 November, p. 7.

Ludlow, M. 2017a. 'Half of outback Qld youths jobless'. Australian Financial Review, 3 November, p. 10.

Ludlow, M. 2017b. 'Labor's mayor backs taxpayer rail-line funds'. Australian Financial Review, 9 November, p. 9.

Ludlow, M. 2017c. 'One Nation scare campaign doing the trick'. Australian Financial Review, 20 November, p. 4.

Ludlow, M. 2017d. “"Robin Hood” Palaszczuk firms for win'. Australian Financial Review, 25 November, p. 6.

McKenna, M. 2016. 'Annastacia Palaszczuk ready to gamble on early poll'. The Australian, 9 March, https:/www.theaustralian.com.au/national-affairs/ state-politics/annastacia-palaszczuk-ready-to-gamble-on-early-poll/news-story/ 4b77fb9e4db4b8a016d1c426b3a0280c.

McKenna, M. 2017. 'Labor's report backs LNP's coal power plan'. The Australian, 1 November, p. 7.

McKenna, M. and Elks, S. 2017. 'Pauline Hanson to target 20 seats at Queensland poll'. The Australian, 3 October, https:/www.theaustralian.com.au/news/paulinehanson-to-target-20-seats-at-queensland-poll/news-story/

ee7b69f34d868b0d5f796397f193b022. 
Mcllroy, T. 2016. 'George Brandis caught on hot mic calling LNP colleagues "mediocre" and "not very good"'. Sydney Morning Herald, 21 November, http:// www.smh.com.au/federal-politics/political-news/george-brandis-caught-on-hotmic-calling-lnp-colleagues-mediocre-and-not-very-good-20161121-gsu432.html.

Madigan, M., Akers, T. and Vogler, S. 2017. 'Absolutely puckered'. Courier-Mail, 22 November, p. 11.

Marszalek, J. 2017. 'Greens take it to Trad'. Courier-Mail, 26 November, p. 4.

Marszalek, J. and Akers, T. 2017a. 'Leading question'. Courier-Mail, 7 November, p. 7.

Marszalek, J. and Akers, T. 2017b. 'Pauline in spotlight'. Courier-Mail, 7 November, p. 8.

Marszalek, J. and Vogler, S. 2017. 'Voters apply the blowtorch'. Courier-Mail, 17 November, p. 6.

Motherwell, S. 2017. 'Behind the scenes of the "Battler Bus"', 11 November, https://www.brisbanetimes.com.au/queensland-election-2017/behind-the-scenes-ofthe-battler-bus-20171111-p4ywxz.html.

Mysunshinecoast.com 2017. 'Tim Nicholls Queensland Media Club address', 21 November, https://mysunshinecoast.com.au/news/news-display/tim-nichollsqueensland-media-club-address, 52521.

Newspoll 2015-17. 'Newspoll', https://www.theaustralian.com.au/national-affairs/ newspoll/qld.

Newspoll 2017. 'Newspoll', https:/www.theaustralian.com.au/national-affairs/ newspoll/qld.

O’Brien, C. 2017. 'Palaszczuk calls election dogged by anti-coal protester, Nicholls questioned about One Nation'. ABC News. 29 October, http://www.abc.net.au/news/ 2017-10-29/queensland-election-palaszczuk-nicholls-dogged-anti-coal-protest/ 9095036.

O'Brien, C. and Briggs, C. 2016. 'LNP indicates it will preference One Nation ahead of Labor at next Queensland election'. $A B C$ News, 26 August, http://www.abc.net.au/news/2016-08-26/lnp-may-preference-one-nation-ahead-oflabor-next-qld-election/7787576.

Peel, C. 2017. 'Action man's hopes may swim with the fishes'. The Australian, 10 November, p. 8.

Peel, C. and Elks, S. 2017. 'Premier asks for LNP vote as Nicholls warns of tax grab'. The Australian, 25 November, p. 11.

Peel, C., Walker, J. and Elks, S. 2017. 'Premier weighs in for a rocky election'. The Australian, 20 November, p. 6.

Repass, D. 1971. 'Issue salience and party choice'. American Political Science Review 65(2), 389-400.

Robertson, J. 2017. 'Queensland election: Labor's costings aim to hit wealthy to curb state debt, LNP promises cheaper power'. ABC News, 23 November, http:/www.abc.net.au/news/2017-11-23/queensland-election-costings-laborcostings-aim-curb-state-debt/9185480.

Schliebs, M., Peel, C. and Elks, S. 2017. 'How Adani veto turned tide for ALP'. The Australian, 9 December, p. 9.

Scott, L. 2017. 'Just 19 votes got him a seat in the Senate. So who is Fraser Anning?' Courier-Mail, 9 December, p. 14. 
Smith, L. 2017. 'Strelow: Why I'm risking it all on this massive gamble'. Morning Bulletin (Rockhampton), 6 November, https://www.themorningbulletin.com.au/ news/strelow-why-im-risking-it-all-on-this-massive-gamb/3258274.

Syvret, P. 2016. 'A tale of two states'. Courier-Mail, 25 November, p. 12.

Tilley, C. 2017. 'Queensland election: Australia's first with real-time donations disclosures. What can we learn?' ABC News, 6 December, http://www.abc.net.au/news/ 2017-11-24/political-donations-in-queensland-revealed-in-real-time/9145608.

Trott, K. 2017. 'Hanson's battler bus built where?' Westender, 12 November, http://westender.com.au/hansons-battler-bus-made-qldvotes.

Viellaris, R. and Vogler, S. 2017. 'Palaszczuk digs a hole for Adani'. Courier-Mail, 4 November, p. 9.

Vogler, S. 2017a. 'Queensland state election: Path clear for Premier Annastacia Palaszczuk'. Courier-Mail, 30 June, http://www.couriermail.com.au/news/ queensland/queensland-government/queensland-state-election-path-clear-for-

premier-annastacia-palaszczuk/news-story/15a86c17889a1b1b6b7a17e832b9c9ed.

Vogler, S. 2017b. 'Security detail steps in as defiant anti-Adani protesters dog Premier'. Courier-Mail, 31 October, p. 5.

Vogler, S. 2017c. 'Champ's in her corner'. Courier-Mail, 20 November, p. 4.

Vogler, S. 2017d. 'Trail fails'. Courier-Mail, 25 November, p. 8.

Vogler, S. 2017e. 'Lockout laws look licked'. Courier-Mail, 2 January, p. 12.

Vogler, S. and Wardill, S. 2017. 'MP sacking leads to poll', Courier-Mail, 29 October, p. 4.

Walker, J. 2017a. “"Coward” call from stranded Hanson'. The Australian, 30 October, p. 7.

Walker, J. 2017b. 'Harsh reality Nicholls dare not face'. The Australian, 18 November, p. 18.

Walker, J. 2017c. 'One Nation's preference: Put all sitting MPs last'. The Australian, 12 October, p. 1.

Walker, J. 2017d. 'Parties told: You don't deserve our vote'. The Australian, 14 November, p. 6 .

Wardill, S. 2016. 'Number's up for LNP'. Courier-Mail, 22 April, p. 12.

Wardill, S. 2017a. 'Premier's very powerful secret'. Courier-Mail, 1 November, p. 1.

Wardill, S. 2017b. 'Anning's walk hits Pauline'. Courier-Mail, 21 November, p. 9.

Wardill, S. 2017c. 'Trad on the edge of her seat'. Courier-Mail, 13 November, p. 4.

Wardill, S. 2017d. 'Battle down to a split decision'. Courier-Mail, 24 November, p. 9.

Weston, P. 2017. 'We could have done more for the Coast'. Gold Coast Bulletin, 22 November, p. 8.

Williams, P. D. 2001. 'The Queensland election of 17 February 2001: Reforging the electoral landscape?', Australian Journal of Political Science 36(2), 363-71.

Williams, P. D. 2004. 'The Queensland election of 7 February 2004: The coming of the second Labor hegemony?', Australian Journal of Political Science 39(3), 635-44.

Williams, P. D. 2005. 'Peter Beattie's strategies of crisis management: Mea culpa and the policy "backflip"'. Australian Journal of Public Administration 64(4), 41-52.

Williams, P. D. 2007. 'Defying the odds: Peter Beattie and the 2006 Queensland election'. Australasian Parliamentary Review 22(2), 212-20. 
Williams, P. D. 2010. 'The Queensland election of 21 March 2009: Labor's swim against the tide'. Australian Journal of Political Science 45(2), 277-83.

Williams, P. D. 2015. 'Political chronicle - Queensland, January-June, 2015'. Australian Journal of Politics and History 61(4), 636-45.

Williams, P. D. 2016. 'Political chronicle — Queensland, January-June, 2016'. Australian Journal of Politics and History, 62(4), 625-32.

Williams, P. D. 2017a. 'Political chronicle - Queensland, January-June, 2017'. Australian Journal of Politics and History 63(4), 641-8.

Williams, P. D. 2017b. 'Political chronicle - Queensland, July-December, 2016'. Australian Journal of Politics and History 64(2), 302-10.

Williams, P. D. 2017c. 'Put money on July 15 poll'. Courier-Mail, 3 May, p. 49. 